\title{
METHODS OF TREES EVALUATION WITH THE SITE- SPECIFIC EFFECT FOR MICROCLIMATE IN URBAN ENVIRONMENT: THE CASE OF STUDY NITRA (SLOVAKIA)
}

\author{
JÁN KLEIN, ZDENKA RÓZOVÁ
}

Department of Ecology and Environmental Sciences, Faculty of Natural Sciences, Constantine the Philosopher University in Nitra, Tr. A. Hlinku 1, 94974 Nitra, Slovak Republic; e-mail: jan.klein@ukf.sk, zrozova@ukf.sk

\begin{abstract}
Klein J., Rózová Z.: Methods of trees evaluation with the site-specific effect for microclimate in urban environment: the case of study Nitra (Slovakia). Ekológia (Bratislava), Vol. 36, No. 1, p. 40-51, 2017.

Microclimatic factors in selected vegetation structures have been monitored in a compact historical built-up layout in the Nitra municipality. We have observed relationship between microclimatic factors (air temperature, relative air humidity and surface temperature) and microclimatic environment indices (MEI). MEI were created for selected trees with varied structure on the basis of synthesis of input data (layout samples of canopy layer and urban geometry). They point out the impact of trees and environment on microclimate in an urban environment during hot days. Surface temperature is a significant factor. The model shows that the surface temperature in various structures of trees and varied urban geometry could be identified through MEI. From the microclimatic point of view, the tree cover in the narrow street with 8 MEI has the greatest cooling effect. MEI from 8 to 13 proved the cooling effect with regard to the general diameter of the area. The higher the number of MEI, the lower is the cooling effect of the trees.
\end{abstract}

Key words: MEI, microclimaticfactors, canopylayer, trees, urbangeometry.

\section{Introduction}

Urban environment with its characteristics creates urban climate. Built-up areas with artificial surfaces increase the air temperature. Trees in urbanised environment work as stabilisers and improve the urban climate at the local level depending on the size of its area and structure. Rosenfeld et al. (1995) found out that except increasing the albedo, tree planting may also reduce or efficiently reverse the urban heat island (UHI) effect and conserve energy. Lowering the air temperature by canopy layer, cities will enjoy (a) reduced air conditioning loads in buildings and (b) improved thermal comfort for pedestrians in outdoor urban spaces (Erell et al., 2012). Trees cool the air by evapotranspiration and prevent its overheating by shading the artificial surfaces. A more extensive tree cover may provide significant ecosystem services such as regulation of urban microclimate by moderating temperatures, decrease in the urban water outflow, reduction of the energy consumption of buildings and reduction of air pollution ( $\mathrm{Pa}$ - 
taki et al., 2011; Nowak et al., 2006). Many factors have an impact on the microclimate. Shashua-Bar and Hoffman defined it as 'site-specific effect'. It encompasses the effect of all unspecified variables governing the site microclimate such as geometric configuration, tree characteristics and growth factors. The shading coverage effect expresses the effect of the factors governing the penetration of solar radiation. The canopy shading is determined interalia by canopy shape and depth and leaf area distribution, spacing of the trees and growth factors such as cultivation and irrigation regime. Different levels of shading will produce different levels of the cooling effect (Shashua-Bar, Hoffman, 2000). The maximize cooling effect of shade trees is possible by careful selection of species based on their canopy and leaf characteristics (Bau-Show, Yann-Jou, 2010). As the amount of vegetation cover increases, the radiative temperature recorded by a sensor approximates more closely the temperatures of green leaves, and the canopy temperature at spectral vegetation maximum or complete canopy cover. It is of significance to scrutinize the temperatures of each part of the vegetation-ground system (such as shaded ground, sunny ground, shade vegetation, and sunny vegetation) and to examine the effects of different canopy structures (Caselles et al., 1992; Kimes, 1983). Wang and Akbari (2015) have found out, that increasing tree crown diameter could provide significant reduction of air temperature, than increasing tree height, because of the bigger shading areas could reduce solar energy absorption in summer. Planting trees without space between the tree crowns could maximise to the environmental effect.

The aim of this study was to create a simple assessment tool for evaluation of trees, their structures and environment by the selected variables and to compare it to the measured microclimatic factors of the environment (air temperature, surface temperature, air flow and relative air humidity).

\section{Material and methods}

The study was under way in the locality Compact layout (CL) in the town historical centre of the Nitra municipality in Slovakia according to Klein and Rózová (2016). Land cover of CL consists of the following three elements represented as percentages of tree cover: (1) tree canopy with grass/herbaceous (greenspaces), (2) canopy layer and (3) impervious surface. Buffer of the whole locality points out the ratio of density of the built-up areas (81\%) and green spaces (19\%). Canopy layer overlaps, at the same time, the green spaces and the built-up areas. Its representation is $9 \%$ of the buffer area. The densely built-up historical part of the town represents more of the strengthened sites than the industrial part of the town, and it is a typical example of numerous towns

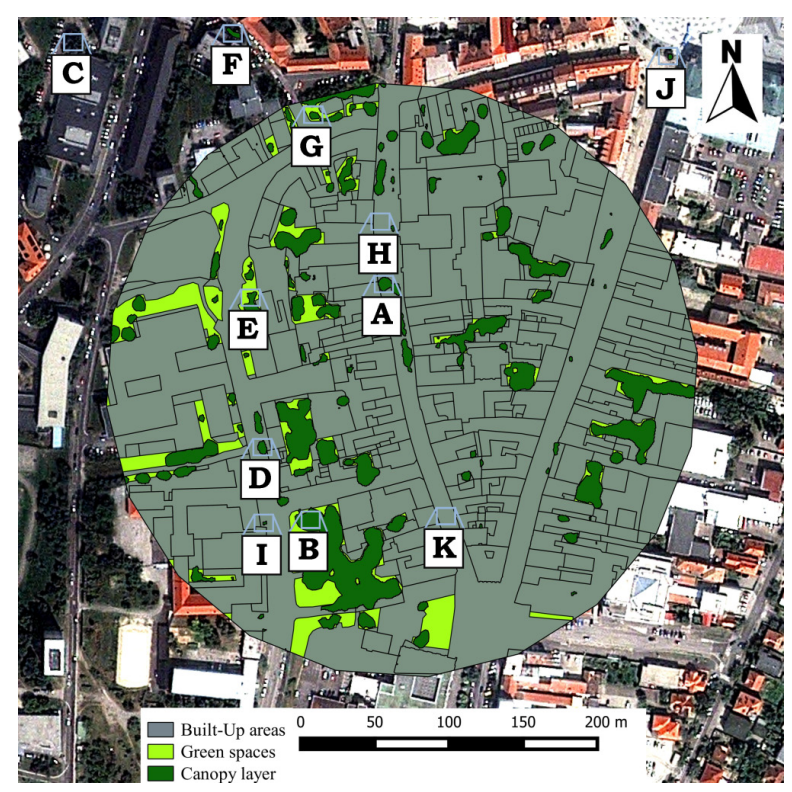

Fig.1.Sites in the locality Compact layout in the town historical centre. 


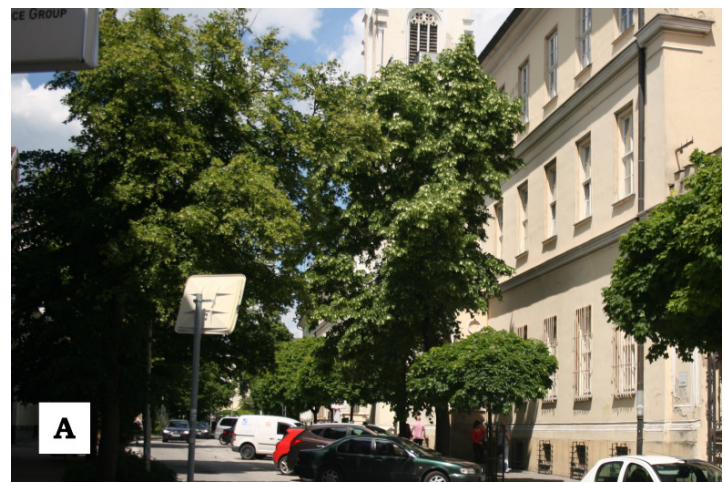

Fig. 2. Site A - Farská street (photo: J. Klein, 2016).

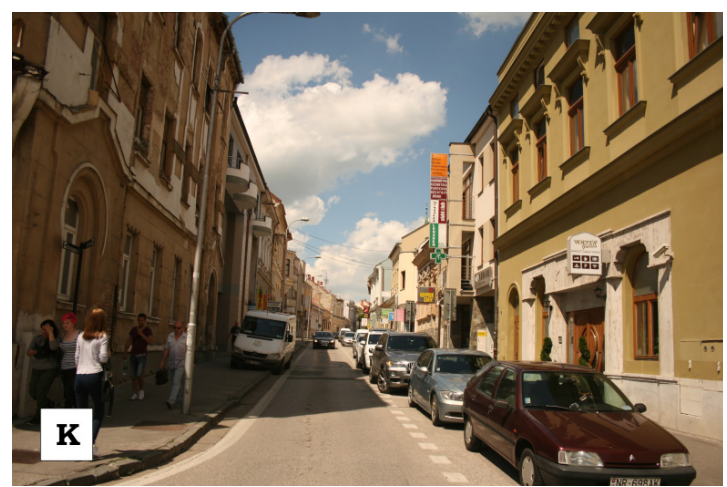

Fig. 3. Hard surface of site K without vegetation effect, Farská street (photo: J.Klein, 2016).

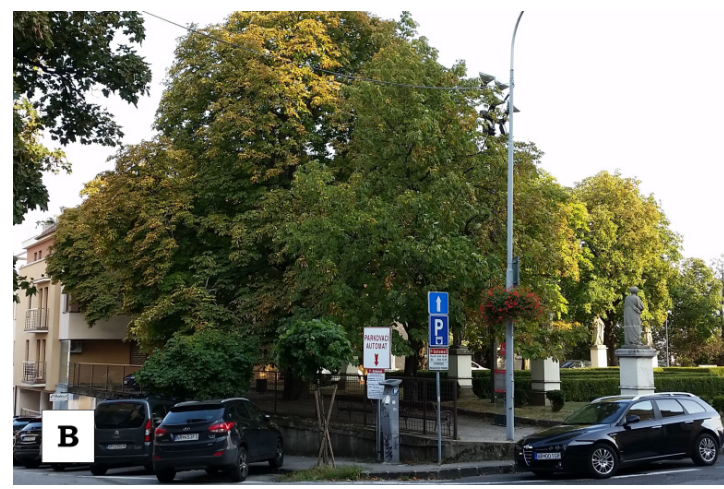

Fig. 4. Site B, Piaristická street (photo: J.Klein, 2016). with urban climate, which is under the influence of reduction of surfaces covered with vegetation (Kuttler, 2008). The size of the buffer $(150 \mathrm{~m})$ was determined based on the distance from A to $\mathrm{K}$ site $(150 \mathrm{~m})$ at the Farská street where the trees showed its cooling effect (Klein, Rózová, 2016). Eleven sites have been selected in the locality (Fig. 1), taking into consideration the northern-southern orientation of the streets. The sites represent the public greenery. Seven sites represent varied structure of woody plants (sites A, B, D, E, G, H and I). One site represents only the strengthened surfaces without any impact of vegetation (site $\mathrm{K}$ ). Three supplement sites are located outside the buffer (sites C, F, J). In the sites $\mathrm{I}, \mathrm{H}$ and $\mathrm{A}$, the temperature of the tree bark has also been recorded. The sites I and $\mathrm{H}$ represent diseased woody plants that are visually recognisable (Fig. 11).

The site A (Fig. 2) is located at the Farská street with an alley of trees in a narrow street corridor. The tree cover is composed of Tilia cordata (Mill.) with Acer sp. (cultivar). In this street, there is also the site $\mathbf{K}$ (Fig. 3), which represents only the spaces without vegetation (Klein, Rózová, 2016).

In the site B (Fig. 4), there are adult trees, mostly Aesculus hippocastanum (L.) and Acer pseudoplatanus (L.) at the Piaristická street. It is small and square bordered from three sides. The studied tree cover is complemented here by trimmed shrubs.

The site E (Fig. 5) is located at the Piaristická street and it goes to an open space of a car park. The tree cover is composed of Chamaecyparis pisifera, which is situated in the grass traffic island. A part of the site is densely covered by Hedera helix (L.).

The site $\mathbf{C}$ (Fig. 6) at the Durkova street is of open space character with the tree cover of Tilia cordata (Mill.). The site has the biggest diversity of neighbouring trees.

The site D (Fig. 7) is at the Piaristická street. In the narrow part of the street that leads to the open space of the small square of the site B, there is the tree cover of Acer platanoides (L.).

The site $\mathbf{F}$ (Fig. 8) is located at the Jozef Vurum street in a narrow street space with three young individuals of Fraxinus sp. (cultivar) in a grassy island.

The site $\mathbf{G}$ (Fig. 9) is located in the Na vŕšku square and it is composed by an open space with a chapel in the middle. The tree cover consists of young individuals of Tilia cordata (Mill.) in a grass traffic island. 
In the site J (Fig. 10), there are separate trees of Corylus colurna (L.) along the margin of the Svätopluk square. The site is composed of an open space.

The site $\mathbf{H}$ (Fig. 11) is located to the north of the site A at the Farská street in a narrow street corridor. The tree Tilia cordata (Mill.) is a diseased individual, which is visually recognisable (withered branches).

In the site I (Fig. 11), there is also a diseased individual of T. cordata (Mill.) that is situated opposite to the site B in the margin of a small square at the Piaristická street.

\section{Measurements in research areas}

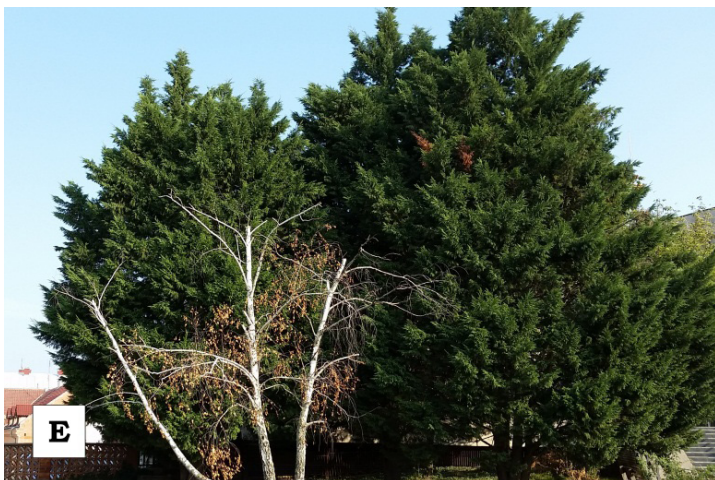

Fig. 5. Site E, Piaristická street (photo: J.Klein, 2016).

Microclimatic data (air temperature, relative air humidity, surface temperature and air flow) have been obtained by the anemometer TSI VelociCalc $9565-$ P. Measurements were taken at midday (from 12:00 till 13:00 of the summer time) in the areas of high pressure and the air flow of maximum $2 \mathrm{~m} / \mathrm{s}$. The surface on which temperature was measured represents only asphalt with an exception of the site J, where there was natural stone paving. The site has been selected by taking into consideration the geometry of the street and tree cover. Measurements have been carried out in the shade of the tree cover directly under a tree or under the biggest individual from the tree cover. The measuring probe has been located at the height of $150 \mathrm{~cm}$. The measurements were carried out from July to August 2015. The data have been statistically evaluated by the one-way analysis of variance (ANOVA) test and verified by Tukey's honest significant difference (HSD) test of the Statistica 7 software.

\section{Structure of vegetated areas}

Visual processing of the tree cover structure has been made by normalised difference vegetation index from the infrared images of Pleiádes Satellite Imagery (2014) of high-resolution $\left(0.5^{*} 0.5 \mathrm{~m} / \mathrm{pixel}\right)$. Because canopy layer may be discontinuous between urban structures, accurate representation of UHI requires high resolution of satellite imagery (Nichol, 1994). The selected locality has been reclassified, recoded and vectorised in the Quantum GIS 2.10.1 Pisa software. The objects of buildings have been taken from OSM maps (openstreetmap.org) and finished according to the images and current status. The output represents the vector objects of anthropogenic surfaces, green surfaces and the canopy layer. Canopy layer (Fig. 1 ) is a healthy tree cover (on the basis of a good chlorophyll reflectance). The sites $\mathrm{H}$ and I with their diseased individuals do not have any or have only a small object of visualisation (canopy layer - Fig. 1) that also shows their deteriorated health condition.

\section{Evaluation of vegetation structure with site-specific effect}

Microclimatic environment indices are composed by five factors (Table 1):

- Green spaces (GS) - the presence/absence $(1 ; 2)$ of grassy surfaces in the spaces under trees.

- $\quad$ Neighbouring trees (NT) - mutual distance of trees in relation to the intersection of crowns (1-4, where $4=$ separate tree; $3=$ neighbouring trees in a distance more than the width of its crown; 2 = crowns are in contact;

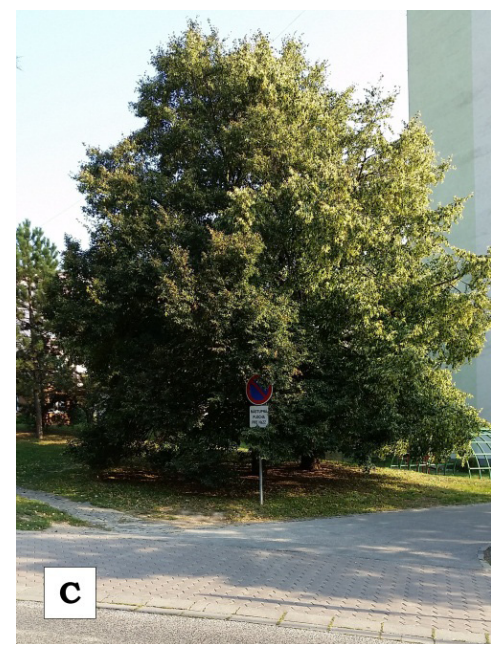

Fig. 6. Site C, Durkova street (photo: J.Klein, 2016). 
$1=$ crowns have impact on each other).

- Openness of spaces (OS) - average distance from four marginal points of a street corridor subsequently converted by rounding the indexed number (up to $10 \mathrm{~m}=1 ; 10-20 \mathrm{~m}=2$ and the like). If we were not able to determine the fourth marginal point, the average of the remaining three was multiplied by 1.5. The individual points are patterned on the distance from -1 to 7 ).

- Crown size (CS) - average width of a tree crown or tree crowns of the whole tree cover in metres from the biggest to the smallest (1-5, where $1=$ site B (Fig. 3) and site C (Fig. 8); $2=$ site A (Fig. 2) and site D (Fig. 4); 3 = site E (Fig. 6); $4=$ sites H, I (Fig. 7) and site F (Fig. 10); 5 = site G (Fig.11) and site J (Fig. 9)).

- Crown density $(C D)$ - density of the sunspots in the tree cover shade $(1-5$, where $1=$ dense crown (sites A, E, C, B); $2=$ sites D and J; $3=$ site G; $4=$ sites H and I; $5=$ thin crown (site F)). Shade factor plays a major role in determining the cooling effect of the site. Different levels of shading will produce different levels of the cooling effect. The shading coverage effect expresses the effect of the factors governing the penetration of solar radiation (Shashua-Bar, Hoffman, 2000).

MEI is a numerical expression of the 'site-specific effect'. They are the selected variables such as greenspaces,

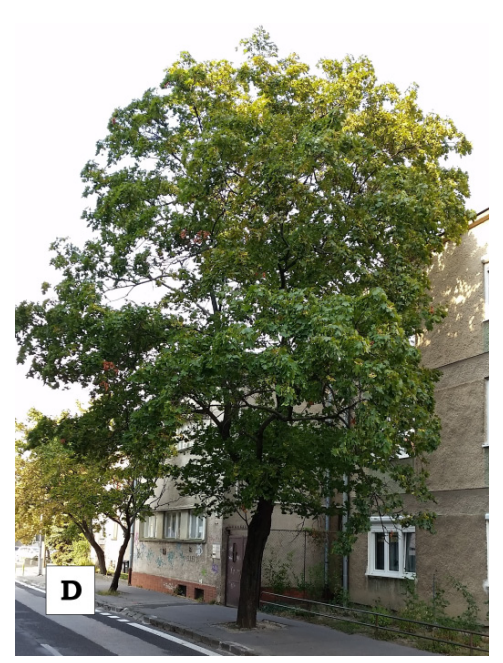

Fig. 7. Site D, Piaristická street (photo: J.Klein, 2016). neighbour trees, openess of spaces, crown density and crown size. Shashua-Bar and Hoffman (2000) have mentioned it as the effect of all unspecified variables governing the site microclimate such as geometric configuration, tree characteristics and growth factors. The lowest number of MEI expresses the best characteristics of the 'site-specific effect' from the viewpoint of the potential cooling effect of vegetation and the potential impact of street configuration on the microclimate. The highest number expresses the potentially lowest cooling effect of vegetation and the potential impact of street configuration on the microclimate. The primal expression of a potential progression for comparing the microclimatic factors displayed through the MEI is showed in Table 2. MEI are represented by the sites, and they are linked to them. To check the relation between the 'site-specific effect' displayed through MEI and the selected microclimatic factors, the linear regression model has been used.

\section{Results and discussion}

In evaluating the data of the measured microclimatic factors - air flow, air temperature, relative air humidity and surface temperature in

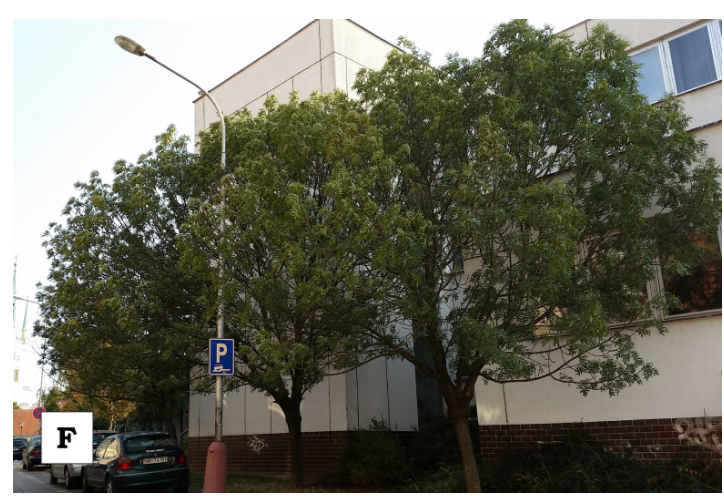

Fig. 8. Site F, Jozef Vurum street (photo: J.Klein, 2016). the selected sites - we have used the one-way ANOVA analysis. The difference in the surface temperature factor (Fig. 12) amongst the sites was statistically significant (oneway ANOVA, $\alpha=0.05, \mathrm{df}=10, p$ $=0.000) . P$ value has been verified by Tukey's HSD test. $P<0.05$ was amongst the sites $\mathrm{A}, \mathrm{B}, \mathrm{C}, \mathrm{E}$ and $\mathrm{K}$. The air flow has been evaluated only in the selected sites (Fig. 13) for the check. None of the sites ex- 
T a b le 1 . Overview of the sites and factors $(f)$ for the created MEI.

\begin{tabular}{|l|l|l|l|l|l|l|l|l|l|l|l|}
\hline \multicolumn{10}{|c|}{ Sites } \\
\hline f & A & B & C & D & E & F & G & H & I & J & K \\
\hline OS & 2 & 5 & 5 & 3 & 7 & 2 & 4 & 3 & 4 & 6 & - \\
CD & 1 & 1 & 1 & 2 & 1 & 5 & 3 & 4 & 4 & 2 & - \\
GS & 1 & 1 & 1 & 2 & 1 & 1 & 1 & 2 & 2 & 2 & - \\
NT & 2 & 1 & 3 & 3 & 1 & 2 & 2 & 4 & 4 & 4 & - \\
CS & 2 & 1 & 1 & 2 & 3 & 4 & 5 & 4 & 4 & 5 & - \\
If & 8 & $\mathbf{9}$ & $\mathbf{1 1}$ & $\mathbf{1 2}$ & $\mathbf{1 3}$ & $\mathbf{1 4}$ & $\mathbf{1 5}$ & $\mathbf{1 7}$ & $\mathbf{1 8}$ & $\mathbf{1 9}$ & x \\
\hline \multicolumn{10}{|c|}{ Microclimatic environment indices (MEI) } \\
\hline
\end{tabular}

$\mathrm{T}$ a b l e 2. Comparison of the sites according to MEI and microclimatic data ordered from the lowest to the highest for the individual factors $(\mathrm{H}(\mathrm{MEI})$, relative air humidity visualised through MEI; AT(MEI), air temperature visualised through MEI; ST(MEI), surface temperature visualised through MEI).

\begin{tabular}{|c|c|c|c|c|}
\hline H(MEI) & AT(MEI) & ST(MEI) & MEI & Sites \\
\hline 13 & 8 & 8 & 8 & $\mathrm{~A}$ \\
\hline 8 & 11 & 11 & 9 & $\mathrm{~B}$ \\
\hline 17 & 13 & 13 & 11 & $\mathrm{C}$ \\
\hline 11 & 19 & 9 & 12 & $\mathrm{D}$ \\
\hline 15 & 14 & 19 & 13 & $\mathrm{E}$ \\
\hline $\mathrm{x}$ & 17 & 17 & 14 & $\mathrm{~F}$ \\
\hline 9 & 9 & 12 & 15 & $\mathrm{G}$ \\
\hline 19 & 12 & 14 & 17 & $\mathrm{H}$ \\
\hline 14 & $\mathrm{x}$ & 15 & 18 & $\mathrm{I}$ \\
\hline 12 & 18 & 18 & 19 & $\mathrm{~J}$ \\
\hline 18 & 15 & $\mathrm{x}$ & $\mathrm{x}$ & $\mathrm{K}$ \\
\hline
\end{tabular}

ceeded $2 \mathrm{~m} / \mathrm{s}$ according to the methodology. The site $\mathrm{F}$ showed higher values of the air flow in comparison with the other sites, though the difference was not statistically significant (one-way ANOVA, $a$ $=0.05, \mathrm{df}=4, p=0.000)$. Tukey's HSD test has not shown significance. We consider this fact important

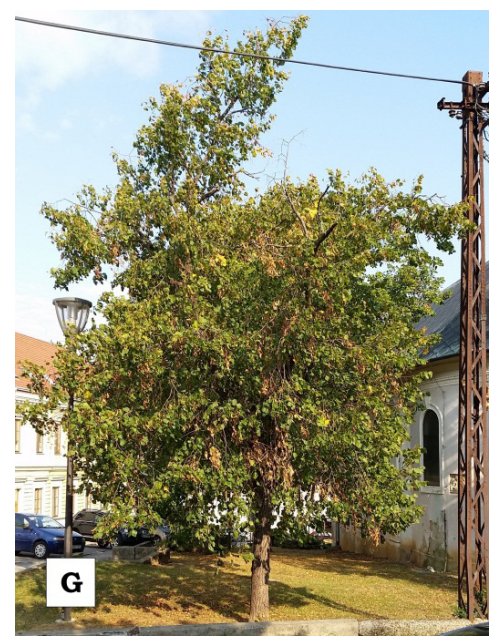

Fig. 9. Site G, Na vŕšku square (photo: J.Klein, 2016).

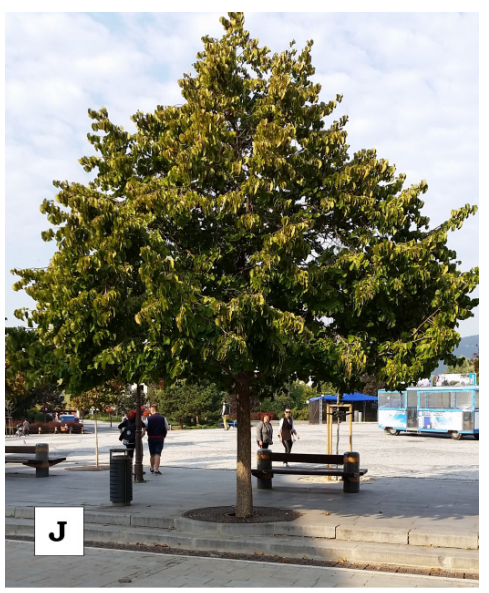

Fig. 10. Site J, Svätopluk square (photo: J.Klein, 2016). for comparing the microclimatic factors amongst the sites. The differences amongst the sites depending on the air temperature (Fig. 14) and relative air humidity (Fig. 15) were not statistically significant at the level of significance $\alpha=0.05$.

The sites were arranged by the created MEI from the lowest to the highest (Figs 1214). The box plots show the measured microclimatic data in the sites. Linear fit points out the sites being on the uptrend (depending on the factors).

The sites arranged from the lowest value of MEI to the highest value of MEI were compared to the sites ordered from the lowest value to the highest value in the units 


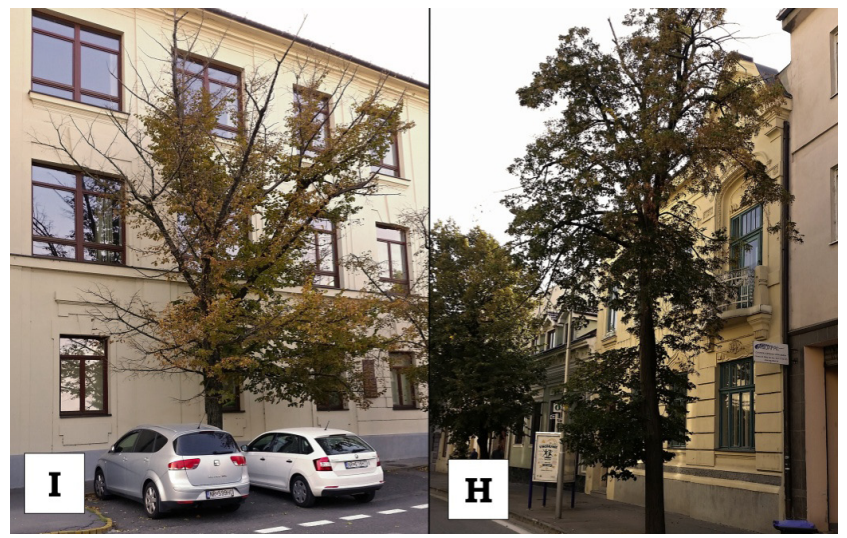

Fig. 11. Diseased trees of both Site I, Piaristická street, and site H, Farská street (photo: J.Klein, 2016).

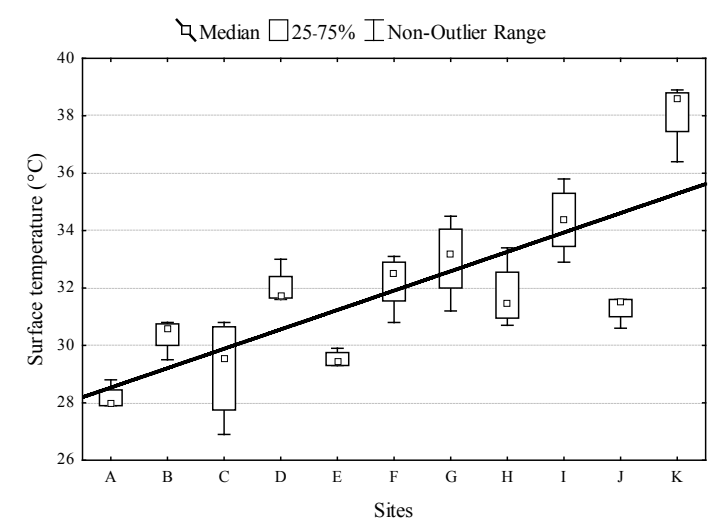

Fig. 12. Surface temperature on sites, arranged by MEI.

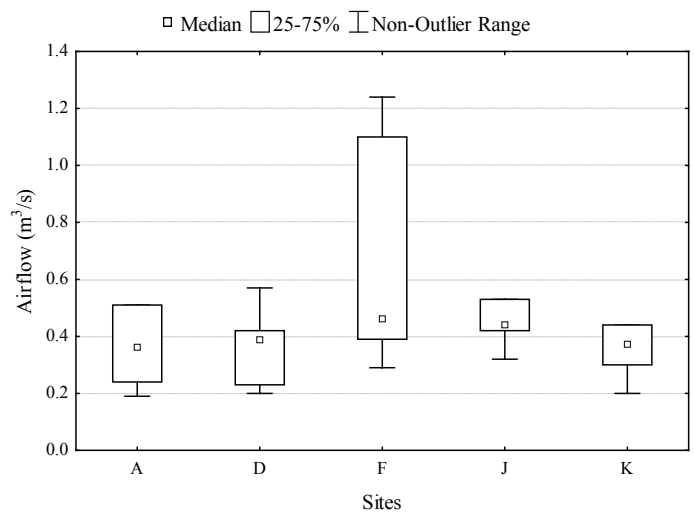

Fig. 13. Airflow on sites, arranged by MEI. of the microclimatic factors displayed through MEI (Tables 3-5). The overall overview can be seen in Table 2. To check the upward tendency (or the downward tendency in the case of relative humidity), we compared MEI with the measured microclimatic data by simple linear regression. The regression analysis for the surface temperature (Fig. 16) shows that if we increase the MEI by one unit, the surface temperature will be increased by $1.01{ }^{\circ} \mathrm{C}$. Even when the Pearson correlation coefficient $(r=$ $0.729)$ shows the high degree of dependence, the quality of the model (coefficient of determination) $\left(\mathrm{r}^{2}=\right.$ 0.532 ) is only $53.2 \%$. This indicated that different structure of canopy layer could help to reduce the surface temperature. If we consider the site J (MEI 19), the surface of which consists of natural stone with lower temperature capacity than asphalt, by its omission, we obtain a more precise estimation. Then we will increase the precision of the model to $67.8 \%$ (surface temperature: MEI: $y$ $=-17.9141+1.0474^{\star} \mathrm{x} ; r=0.8232 ; p$ $\left.=0.0000 ; \mathrm{r}^{2}=0.6777\right)$.

Growing tendency of air temperature and relative air humidity according to MEI in the sites has not shown itself to be statistically significant. Regression analysis has proved the low model quality (Figs 17 and 18). Even when considering the mentioned site J, the mod- 
el quality was not increased (air temperature: MEI: $\mathrm{y}=-36.9829+$ $1.4101^{\star} \mathrm{x} ; r=0.3448 ; p=0.0293 ; \mathrm{r}^{2}$ $=0.1189$; relative humidity: MEI: $\mathrm{y}$ $=16.6009-0.0977^{\star} \mathrm{x} ; r=-0.1837 ; p$ $\left.=0.2565 ; r^{2}=0.0338\right)$. Tukey's HSD test has not shown significance for the $p$ value of one-way ANOVA.

The average air temperature in the locality was $31.2^{\circ} \mathrm{C}$. The average relative air humidity was $29.7 \%$, and the average surface temperature was $35.9^{\circ} \mathrm{C}$. The sites with value of the observed factor lower than the average values of the whole locality factors had cooling effect on the surroundings. The factor of surface temperature points to the cooling effect in the sites with 8, 9, 11 and 13 MEI (Table 3). The factor of air temperature points to the cooling effect in the sites with $8,11,13,14$ and 19 MEI (Table 5). The surroundings of the site J with 19 MEI consists of a paving of natural stone. We assume that this factor has an impact on the air temperature in the site. The factor of relative air humidity points to the cooling effect in the sites with 8 , 11, 13 and 17 MEI (Table 4).

The site $\mathrm{H}$ with 17 MEI represents a diseased tree with potentially lower transpiration capability. We presume that the site is under influence of the street canyon effect of which the canopy layer may have an impact on the surrounding sites. The healthy tree cover of the site A with $8 \mathrm{MEI}$, which is in approximately $50 \mathrm{~m}$ distance from the diseased tree in the site $\mathrm{H}$ with $17 \mathrm{MEI}$, represents the $16.7 \%$ difference in the relative air humidity. We assume

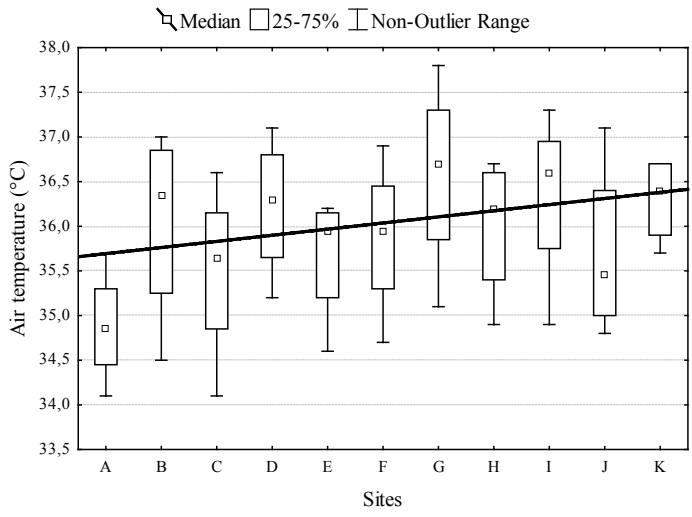

Fig. 14. Air temperature on sites, arranged by MEI.

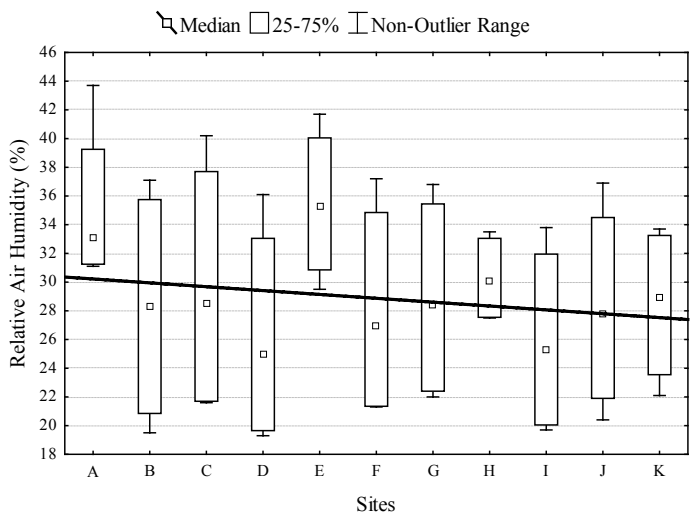

Fig. 15. Relative air humidity on selected sites, arranged by MEI.

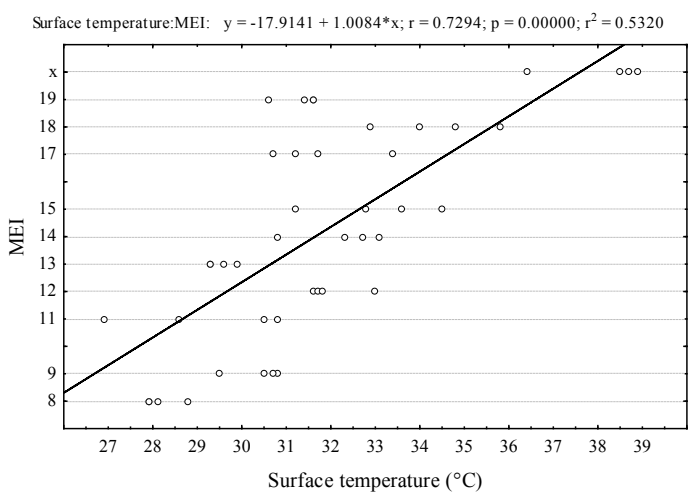

Fig. 16. Relation between MEI and the surface temperature in the sites. 
$\mathrm{T} \mathrm{a} \mathrm{b} \mathrm{l} \mathrm{e} \mathrm{3.} \mathrm{Surface} \mathrm{temperature} \mathrm{in} \mathrm{the} \mathrm{sites} \mathrm{with} \mathrm{MEI} \mathrm{arranged}$ from the lowest to the highest value. Negative values in differences point to the cooling effect of the tree cover $(\Delta S T$, average surface temperature; $r \Delta \mathrm{ST}$, difference of the site from the average of the whole locality; $R \Delta \mathrm{ST}$, difference of the site from the average of the whole locality in percentage).

\begin{tabular}{|c|c|c|c|c|}
\hline Sites & MEI & $\boldsymbol{\Delta S T}\left({ }^{\mathbf{}} \mathbf{C}\right)$ & $\boldsymbol{r} \boldsymbol{\Delta S T}\left({ }^{\circ} \mathbf{C}\right)$ & $\boldsymbol{R} \Delta \mathbf{S T}(\%)$ \\
\hline A & 8 & 28.18 & -3.02 & -9.69 \\
\hline C & 11 & 29.20 & -2.00 & -6.40 \\
\hline E & 13 & 29.53 & -1.67 & -5.36 \\
\hline B & 9 & 30.38 & -0.82 & -2.64 \\
\hline J & 19 & 31.30 & 0.10 & 0.33 \\
\hline H & 17 & 31.75 & 0.55 & 1.77 \\
\hline D & 12 & 32.03 & 0.83 & 2.65 \\
\hline F & 14 & 32.23 & 1.03 & 3.29 \\
\hline G & 15 & 33.03 & 1.83 & 5.86 \\
\hline I & 18 & 34.38 & 3.18 & 10.19 \\
\hline K & $\mathrm{x}$ & 38.13 & 6.93 & 18.69 \\
\hline
\end{tabular}

T a b l e 4. Relative air humidity in the sites with MEI arranged from the lowest to the highest value. Positive values in the differences point to the cooling effect of the tree cover $(\Delta \mathrm{H}$, average air temperature; $r \Delta \mathrm{H}$, difference of the site from the average of the whole locality; $R \Delta \mathrm{HT}$, difference of the site from the average of the whole locality in percentage).

\begin{tabular}{|c|c|c|c|c|}
\hline Sites & MEI & $\Delta H(\%)$ & $r \Delta \mathrm{H}(\%)$ & $R \Delta \mathrm{HT}(\%)$ \\
\hline $\mathrm{E}$ & 13 & 35.45 & 5.79 & 19.53 \\
\hline A & 8 & 35.25 & 5.59 & 18.86 \\
\hline $\mathrm{H}$ & 17 & 30.30 & 0.64 & 2.17 \\
\hline $\mathrm{C}$ & 11 & 29.70 & 0.04 & 0.14 \\
\hline$G$ & 15 & 28.93 & -0.73 & -2.47 \\
\hline $\mathrm{K}$ & $\mathrm{x}$ & 28.40 & -1.26 & -4.40 \\
\hline $\mathrm{B}$ & 9 & 28.30 & -1.36 & -4.58 \\
\hline $\mathrm{J}$ & 19 & 28.20 & -1.46 & -4.91 \\
\hline $\mathrm{F}$ & 14 & 28.10 & -1.56 & -5.25 \\
\hline $\mathrm{D}$ & 12 & 26.35 & -3.31 & -11.15 \\
\hline I & 18 & 26.00 & -3.66 & -12.33 \\
\hline
\end{tabular}

that the site E with 13 MEI shows the highest relative air humidity because of the dense undergrowth of Hedera helix (L.). It is a sempervirent (always green) tree cover.

The tree cover and urban geometry have an impact on the microclimate of the sites. A street canyon with tree cover keeps its cooling effect more than a tree cover in a wider street. Average difference in the air temperature between the site with tree cover (site A) and the one without tree cover (site $\mathrm{K}$ ) in the street canyon was $1.42{ }^{\circ} \mathrm{C}$, whilst the biggest difference achieved was 1.9 ${ }^{\circ} \mathrm{C}$. Difference between the street canyon and the sites that were more open was also bigger. We presume that the air flow and openness of spaces influence the microclimate and their intensity influences the other observed microclimatic factors. The air flow may influence the heating effect of a wide street too. That can be an important factor and should be taken into consideration in the design of trees in a street (Shashua-Bar, Hoffman, 2000). We assume that the street canyon raise the microclimatic effect of the tree cover. A higher tree cover could limit the turbulent flow and have a positive impact on the maintenance of a microclimate. A higher canopy will allow less vertical mixing of warm air down to $1.5 \mathrm{~m}$ above the surface as there is a greater distance for turbulent eddies to penetrate (Hardwicket al., 2015).

\section{Conclusion}

The aim of this study was to create a model for the evaluation of the tree cover in urban environment that quantifies input factors such as green spaces, neighbour trees, 
openess of spaces, crown size and crown density. Using MEI as an assessment tool for trees and their surroundings did not show itself to be significant in relation to the air temperature and relative air humidity. Because of the limited number of measurements used, however, these data should be considered indicative rather than conclusive. The surface temperature is an interesting factor. Statistically significant difference turned out to be between the surface temperatures in the sites whilst the regression analysis points to 53.2 or $67.8 \%$ significance. By that, the MEI point out the microclimatic differences in various tree cover layouts by taking into consideration the urban geometry during hot days. MEI may be used to indicate the temperature of asphalt surface under the tree cover by which the extent of the cooling effect on the surface is quantified. The model shows that by increasing the MEI by one unit, the surface temperature could be increased by $1.01^{\circ} \mathrm{C}$. It means that the tree cover with a low number of MEI has better effects on the surface temperature. The relationships between street structure and urban trees, when quantified, will allow managers to create and maintain functional and beneficial urban trees. Architects or urbanists often take into consideration mainly the aesthetic side of trees rather than the landscape value, suitability of tree types, spaces and connecting green elements. Empirically found benefits of trees are often generally interpreted or mentioned only as background information. One's got to consider how many decision-makers use the cooling function of trees as one of the primary ones. This may be contrary to the aesthetic function and suitability for selected sites. It is very difficult to plant trees in densely built-up localities without green spaces where the cooling function of trees is the most visible. In this type of built-up layout, it is the MEI that may help and through which we can indicate a site-specific effect. It is necessary to know various types of trees and environment structures to be capable to work with MEI values. 
$\mathrm{T} \mathrm{a} \mathrm{b} \mathrm{l} \mathrm{e} \mathrm{5.} \mathrm{Air} \mathrm{temperature} \mathrm{in} \mathrm{the} \mathrm{sites} \mathrm{with} \mathrm{MEI} \mathrm{arranged} \mathrm{from} \mathrm{the}$ lowest to the highest value. Negative values in the differences point to the cooling effect of the tree cover $(\Delta \mathrm{AT}$, average air temperature; $r \Delta \mathrm{AT}$, difference of the site from the average of the whole locality; $R \Delta \mathrm{AT}$, difference of the site from the average of the whole locality in percentage).

\begin{tabular}{|c|c|c|c|c|}
\hline Sites & MEI & $\boldsymbol{\Delta A T}\left(\mathbf{C}^{\mathbf{o}}\right)$ & $\boldsymbol{r} \boldsymbol{\Delta A T}\left(\mathbf{C}^{\mathbf{o}}\right)$ & $\boldsymbol{R} \boldsymbol{\Delta A T}(\%)$ \\
\hline $\mathrm{A}$ & 8 & 34.88 & -1.01 & -2.81 \\
\hline $\mathrm{C}$ & 11 & 35.50 & -0.38 & -1.07 \\
\hline E & 13 & 35.68 & -0.21 & -0.58 \\
\hline J & 19 & 35.70 & -0.18 & -0.51 \\
\hline F & 14 & 35.88 & -0.01 & -0.02 \\
\hline H & 17 & 36.00 & 0.12 & 0.33 \\
\hline B & 9 & 36.05 & 0.17 & 0.47 \\
\hline D & 12 & 36.23 & 0.34 & 0.95 \\
\hline K & $\mathrm{x}$ & 36.30 & 0.42 & 1.14 \\
\hline I & 18 & 36.35 & 0.47 & 1.30 \\
\hline G & 15 & 36.58 & 0.69 & 1.93 \\
\hline
\end{tabular}
Environmental aspects of the urban environment (Environmentálne aspekty urbanizovaného prostredia) supported by the Research \& Development Operational Programme funded by the ERDF.

\section{References}

Bau-Show, L. \& Yann-Jou L. (2010).Cooling effect of shade trees with differentcharacteristics in a subtropical urban park. HortScience, 45(1), 83-86.

Caselles, V., Sobrino, J.A. \& Coll C. (1992). A physical model for interpreting the landsurface temperature obtained by remote sensors over incomplete canopies. Remote Sens. Environ., 39, 203-211. DOI:10.1016/00344257(92)90086-Y.

Erell, E., Pearlmutter, D. \& Boneh D. (2012). Effect of high-albedo materials on pedestrian hermal comfort in urban canyons. The 8th International Conference on Urban Climates. 6-10th August 2012, Dublin, Ireland.

Hardwick, S.R., Toumi, R., Pfeifer, M., Turner, E.C., Nilus, R. \& Ewers R.M. (2015).The relationship between leaf area index and microclimate in tropical forest and oil palm plantation: Forest disturbance drives changes in microclimate. Agric.For.Meteorol., 201, 187-195. DOI:10.1016/j.agrformet.2014.11.010.

Kimes, D.S. (1983).Remote sensing of row crop structure and component temperatures using directional radiometric temperatures and inversion techniques. Remote Sens. Environ., 13, 33-55. DOI:10.1016/00344257(83)90026-3.

Klein, J. \& Rózová Z. (2016).Evaluation of microclimatic factors in different layouts of built-up areas and vegetation cover of urban areas of Nitra municipality. In L. Halada, A. Bača \& M. Boltižiar (Eds.), Landscape and landscape ecology (pp. 236-245). Proceedings of the 17th International Symposiumon Landscape Ecology. Nitra: Institute of Landscape Ecology, Slovak Academy of Sciences.

Kuttler,W. (2008). The urban climate - Basic and applied aspects. In J.M. Marzluff, E. Schulenberger, W. Endlicher, M. Alberti, G. Bradley, C. Ryan, U. Simon \& C. Zum Brunnen (Eds.), Urban ecology (pp.233-248). New York: Springer.

Nichol, J.E. (1994). A GIS-based approach to microclimate monitoring in Singapore's high-rise housing estates. Photogrammetric Engineering and Remote Sensing, 60(10), 1225-1232.

Nowak, D.J., Crane, D.E.\& Stevens J.C. (2006). Air pollution removal by urban trees and shrubs in the United States. Urban Forestry \& Urban Greening, 4(3-4), 115-123. DOI:10.1016/j.ufug.2006.01.007.

Pataki, D.E., Carreiro, M.M., Cherrier, J., Grulke, N.E., Jennings, V., Pincetl, S.,Pouyat, R.V., Whitlow, T.H. \& 
Zipperer W.C. (2011).Coupling biogeochemical cycles in urban environments: ecosystem services, green solutions, and misconceptions. Frontiers in Ecology and the Environment, 9(1), 27-36. DOI:10.1890/090220.

Rosenfeld, A.H., Akbari, H., Bretz, S., Fishman, B.L., Kurn, D.M., Sailor, D. \& Taha H. (1995). Mitigation of urban heat islands: materials, utility programs, updates. Energy and Buildings, 22(3), 255-265. DOI:10.1016/0378-7788(95)00927-P.

Shashua-Bar, L.\& Hoffman M.E. (2000).Vegetation as a climatic component in the design of an urban street: An empirical model for predicting the cooling effect of urban green areas with trees. Energy and Buildings, 31(3), 221-235. DOI:10.1016/S0378-7788(99)00018-3.

Wang, Y. \& Akbari H. (2015). A simulation study of the effects of street tree planting on Urban Heat Island mitigation in Montreal. EIC Climate Change Technology Conference 2015. Montreal, Canada. 